\title{
THE IMPACT OF CATTLE HIDE CLEANLINESS SCORES ON MICROBIAL CONTAMINATION OF CARCASSES DURING SLAUGHTERING
}

\author{
Buket Kallem, Pelin Koçak Kizanlik², Cemil Şahiner², Ergün Ömer Göksoy² \\ ${ }^{1}$ Department of Food Hygiene and Technology, Institute of Health Sciences, \\ Aydin Adnan Menderes University, 09100 Aydin, Turkey \\ ${ }^{2}$ Department of Food Hygiene and Technology, Faculty of Veterinary Medicine, \\ Aydin Adnan Menderes University, 09020 Aydin, Turkey
}

Received 28 July 2021; Received in revised form 4 January 2022; Accepted 20 January 2022

\begin{abstract}
This study aimed to investigate the effects of cleanliness scoring on the microbiological load of hide and the final contamination of cattle carcasses. Fifty cattle were classified from 1 (clean and dry) to 5 (filthy and wet). Aerobic colony count (ACC) and counts of Enterobacteriaceae (EC) and E. coli (ECC) were determined on the brisket, abdominal midline, rump, groin sites of the hides, and brisket, flank, groin, and hock of the carcasses. On hides, ACC ranged from $3.15 \pm 0.13 \mathrm{log} \mathrm{cfu} / \mathrm{cm}^{2}$ in category 1 to $8.14 \pm 0.21 \log \mathrm{cfu} / \mathrm{cm}^{2}$ in category 5. EC and ECC were ranging between $1.13 \pm 0.07 \mathrm{and} 2.80 \pm 0.09 \mathrm{log} \mathrm{cfu} / \mathrm{cm}^{2}$, and $1.21 \pm 0.05$ and $2.15 \pm 0.07 \log \mathrm{cfu} / \mathrm{cm}^{2}$, respectively. While the mean ACC on the carcasses ranged between $2.18 \pm 0.07$ and $2.63 \pm 0.05 \log \mathrm{cfu} / \mathrm{cm}^{2}$ irrespective of the categories, Enterobacteriaceae and E. coli could not be counted due to the detection limits. It was concluded that although the level of bacterial load increased significantly $(\mathrm{P}<0.001)$ with the increasing cleanliness category on the hide of the animals, the reflection of this increasing trend on carcasses and different parts of the carcasses were inconsistent and the hygiene provided in the slaughterhouse and processing line was the main factor to reduce cross-contamination during processing.
\end{abstract}

Key words: cleanliness scoring, cattle carcass, cross-contamination, hide cleanliness, microbial load

\section{INTRODUCTION}

The aerobic bacteria on the cattle hide may reach up to $11 \log \mathrm{cfu} / \mathrm{cm}^{2}$ (1) and may include zoonotic pathogens such as Listeria monocytogenes, Escherichia coli O157:H7, Salmonella spp., Campylobacter spp. which can be transmitted by the soil, water, feedstuff, and/or feces (2).

The tissues under the skin are considered to be sterile before skinning (barrier effect of hide). The contamination of underlying tissues with bacteria, including pathogenic species for

Corresponding author: Prof. Ergün Ömer Göksoy, PhD

E-mail address: eogoksoy@adu.edu.tr

Present address: Department of Food Hygiene and Technology,

Faculty of Veterinary Medicine, Aydin Adnan Menderes University, 09020 Aydin, Turkey

Phone: 0090256 2206000; Fax: 00902562206299

Copyright: (C) 2022 Kallem B. This is an open-access article published under the terms of the Creative Commons Attribution License which

permits unrestricted use, distribution, and reproduction in any medium, provided the original author and source are credited.

Competing Interests: The authors have declared that no competing interests exist.

Available Online First: 11 February 2022

Published on: 15 March 2022

https://doi.org/10.2478/macvetrev-2022-0012 humans, is unavoidable and may occur in several degrees during slaughtering $(3,4)$. The floor and litter are considered the most important sources of contamination due to frequent contact with the flank and brisket $(5,6)$.

It has been generally accepted that there are some interactions between the cleanliness of animals before slaughter and the level of dirt and filth (mud, bedding, manure, etc.) transferred to the carcasses. Appropriate measures on the slaughtering line, especially during the dressing procedures, may limit the cross-contamination from hides to meat via knives, hands, etc. However, published reports on that matter are rather conflicting to several extents. According to some studies, cattle hide plays an important role in the microbial cross-contamination of beef carcass meat during the skinning operation $(6,7)$. In contrast, Van Donkersgoed et al. (8) reported that there was no consistent connection between tags (mud, bedding, and manure) attached to the skin of cattle at slaughter and bacterial load of carcasses. Changes observed in bacterial counts, 
associated with several parameters such as tag scores, hide wetness, line speed, or tag shaven off the hides, were lower than $0.5 \log \mathrm{cfu} / \mathrm{cm}^{2}$. Antic et al. (9) also did not find any significant differences in microbial levels between bovines with different visual hide cleanliness scores. Buncic et al. (10) reported that the correlation between cattle hide cleanliness and hide microbiological status before and after slaughtering was limited and inconsistent, and should be further investigated.

Visually, dirtier hides are generally associated with the significantly higher aerobic colony (ACC) and Enterobacteriaceae count (EC) on hides and dressed carcasses (11). Food business establishments, including slaughterhouses, are required to apply good hygienic practices (GHP) and hazard analysis and critical control point (HACCP) principles-based food safety procedures $(12,13)$. The regulation (12) emphasizes that food business establishments rearing animals should ensure the cleanliness of animals during production and/or slaughter. Similarly, EC Regulation 853/2004 (H2) (13) states hygiene control requirements for slaughter and emphasizes that all animals should be 'clean' before being accepted by the slaughterhouse. In several countries, such as France, Belgium, and the United Kingdom, the cleanliness of animals has been defined as an evaluation criterion. Excessively dirty animals should not be accepted for slaughter $(6,14,15,16)$.

Despite the existing legislations in Turkey enforced by the official veterinarians which require that animals should be clean before slaughter, there is no practical application of carcass cleanliness scores (from 1 to 5) at the abattoir level $(14,17)$.

The work presented here aimed to determine the effect of visual cleanliness of cattle hide on carcass contamination as indicated by ACC, EC, and E. coli count (ECC) in cattle slaughtered in an abattoir in the Western part of Turkey.

\section{MATERIAL AND METHODS}

\section{Cleanliness category evaluation and sampling}

All visual inspection and slaughtering procedures of this work were carried out in a middle-scale slaughterhouse located in the Western part of Turkey. The slaughterhouse belonged to the municipal government of that region with a high level of hygienic measures, complying with all the requirements of the Turkish Food Safety Authority, and controlled by both municipal and state veterinarians. The premises had effectively employed the HACCP plan and GHP applications. Visual inspection procedures (scoring) were conducted according to the Food Standard Agency Guidelines (14) while animals were at the lairage. All cattle categorized were male Holstein-Friesian calves, received from various farms. The procedure applied was simply categorization of cattle from 1 (clean and dry) to 5 (filthy and wet) based on their cleanliness. Fifty cattle (10 animals for each cleanliness category) were selected for sampling after visual scoring. Sampling was conducted immediately after bleeding when the animals were hanged by their feet. Both scoring and sampling procedures were conducted on 5 different days.

Before the slaughtering procedure, just before the trail started, the knives, and steels were immersed into alcohol ( $90 \%$ ethanol), were flamed and placed into holding rocks with circulating water at $82-85^{\circ} \mathrm{C}$ to prevent contamination. Manipulations conducted during slaughtering procedures (e.g., skinning) for each carcass was carried out using 2 knives which were sanitized in hot water lines before their next use and/or whenever it was necessary.

Contamination was avoided by eliminating contact with aprons, water splashing, and gastrointestinal rupturing during evisceration. Samples from the hides were taken immediately after bleeding and before hide removal from brisket, abdominal midline, rump and groin sites of the animals, where most of the manipulations and handling are considered to be carried out during hide removal. At the end of the splitting procedure and just before chilling, carcass samples were collected from each carcass's brisket, flank, groin, and hock (6).

\section{Microbiological analysis}

The microbiological results were evaluated based on the colony counting method (18), expressed in $\mathrm{cm}^{2}$ on swabbing areas of $25 \mathrm{~cm}^{2}$. For each cleanliness category, 40 samples were taken from the hides and carcasses, which were assessed for ACC, EC, and ECC.

Both hide and carcass were sampled by using the double swabbing method in which swabs (Or-Bak Swap 150502) wetted with buffered peptone water (Oxoid CM 1049) were rolled on the surface of hide/carcass by using a template of $25 \mathrm{~cm}^{2}$ surface area. Following this, dry swabs were rolled over the same area. Both swabs (dry and wet) were put into tubes containing $10 \mathrm{ml}$ of buffered peptone water (Oxoid CM 1049). Samples were transferred 
within 1 hour in iceboxes $\left(4 \pm 1{ }^{\circ} \mathrm{C}\right)$ containing cold packs to the microbiology laboratory of FVMADU, Department of Food Science and Technology.

The ACC levels and the numbers of Enterobacteriaceae and E. coli were determined in the samples of hides and carcasses. The tubes containing swabs were stirred by using a stirrer (Biosan, EU) for $2 \mathrm{~min}$ and serial dilutions were made. The inoculations from the dilutions were applied on Plate Count Agar (Oxoid CM 463), Violet Red Bile Glucose Agar (Oxoid CM 485), and Tryptone Bile X-Glucuronide Agar (Oxoid CM 945) for ACC and enumeration of EC and ECC. The plates incubation was performed at $30{ }^{\circ} \mathrm{C}$ for $48-72 \mathrm{~h}$ for $\mathrm{ACC}$ and $37^{\circ} \mathrm{C}$ for $24 \mathrm{~h}$ for $\mathrm{EC}(19,20)$. For enumeration of ECC, Tryptone Bile X-Glucuronide Agar plates were incubated at $37^{\circ} \mathrm{C}$ for $4 \mathrm{~h}$ and were then moved to another incubator at $44{ }^{\circ} \mathrm{C}$ for $18-24 \mathrm{~h}$. Following incubation, opaque colonies with bluegreen color were identified as E. coli (21).

\section{Statistical analysis}

SPSS version 22 (USA, 2013) was used for statistical analysis. The significances between the cleanliness categories for both carcasses and hides $(\mathrm{P}<0.05)$ were evaluated by using Kruskal-Wallis Variance Analysis for ACC, EC, and ECC on hide and only for ACC on the carcass. Groups with significant differences $(\mathrm{P}<0.05)$, were further analyzed with the post-hock Duncan test.

\section{RESULTS}

The results obtained from hide samples showed that ACC, EC, ECC, and the numbers of countable plates had an increasing trend with each consecutive category. In Category 1 there were 16 positive countable samples (40\%) for EC and 3 (7.5\%) for ECC.

ACC ranged from $3.15 \pm 0.13 \log \mathrm{cfu} / \mathrm{cm}^{2}$ in Category 1 to $8.14 \pm 0.21 \log \mathrm{cfu} / \mathrm{cm}^{2}$ in Category 5 (Table 1). There were significant differences between the categories $(\mathrm{P}<0.001)$, except between Category 4 and Category 5. The levels of EC on the hide samples and the numbers of countable plates increased with the increasing categories, but this trend was not consistent for all groups as seen for Category 1, 2, and 3 (Table 1). No significant differences were found between categories 3, 4, and 5 . The mean EC level was $1.13 \pm 0.07 \log \mathrm{cfu} / \mathrm{cm}^{2}$ for Category 1, but it was $2.60 \pm 0.07$ for Category 5 . The ECC levels had the lowest mean value in Category $2\left(1.21 \pm 0.05 \log \mathrm{cfu} / \mathrm{cm}^{2}\right)$ and the highest in Category $4\left(2.15 \pm 0.07 \log \mathrm{cfu} / \mathrm{cm}^{2}\right) \quad(\mathrm{P}<0.001)$ (Table 1).

In carcass samples, results of ACC were ranging between $2.18 \pm 0.07$ and $2.63 \pm 0.05 \log \mathrm{cfu} / \mathrm{cm}^{2}$. The lowest value was observed in Category 1, whereas the highest was observed in Category 2. The elevation observed in ACC was not consistent with the cleanliness scores. There were also significant differences between the categories, however, they

Table 1. The levels of hygiene indicators obtained from hides and carcasses from different cleanliness categories $\left(\log \mathrm{cfu} / \mathrm{cm}^{2}\right)$

\begin{tabular}{|c|c|c|c|c|c|c|c|c|}
\hline \multirow[b]{2}{*}{ Category } & \multicolumn{6}{|c|}{ Hide } & \multicolumn{2}{|c|}{ Carcass } \\
\hline & $\mathbf{N}$ & $\begin{array}{c}\text { ACC } \\
\operatorname{Mean} \pm \text { SE }\end{array}$ & $\mathbf{N}$ & $\begin{array}{c}\text { EC } \\
\operatorname{Mean} \pm \text { SE }\end{array}$ & $\mathbf{N}$ & $\begin{array}{c}\text { ECC } \\
\operatorname{Mean} \pm \text { SE }\end{array}$ & $\mathbf{N}$ & $\begin{array}{c}\text { ACC } \\
\text { Mean } \pm \text { SE }\end{array}$ \\
\hline $\begin{array}{l}1 \\
\text { Clean and dry }\end{array}$ & 37 & $3.15 \pm 0.13^{\mathrm{d}}$ & 16 & $1.13 \pm 0.07^{\mathrm{c}}$ & 3 & $1.32 \pm 0.03^{c}$ & 32 & $2.18 \pm 0.07^{b}$ \\
\hline $\begin{array}{l}2 \\
\text { Slightly dirty }\end{array}$ & 40 & $5.43 \pm 0.13^{\mathrm{c}}$ & 40 & $1.82 \pm 0.03^{\mathrm{b}}$ & 16 & $1.21 \pm 0.05^{\mathrm{c}}$ & 36 & $2.63 \pm 0.05^{\mathrm{a}}$ \\
\hline $\begin{array}{l}3 \\
\text { Dirty }\end{array}$ & 40 & $6.60 \pm 0.15^{b}$ & 37 & $2.80 \pm 0.09^{\mathrm{a}}$ & 30 & $1.85 \pm 0.07^{\mathrm{ab}}$ & 38 & $2.54 \pm 0.06^{\mathrm{a}}$ \\
\hline $\begin{array}{l}4 \\
\text { Very dirty }\end{array}$ & 40 & $7.98 \pm 0.10^{\mathrm{a}}$ & 40 & $2.78 \pm 0.06^{\mathrm{a}}$ & 33 & $2.15 \pm 0.07^{\mathrm{a}}$ & 38 & $2.31 \pm 0.06^{b}$ \\
\hline $\begin{array}{l}5 \\
\text { Filthy and wet }\end{array}$ & 40 & $8.14 \pm 0.21^{\mathrm{a}}$ & 38 & $2.60 \pm 0.07^{\mathrm{a}}$ & 33 & $1.73 \pm 0.09^{b}$ & 38 & $2.27 \pm 0.06^{b}$ \\
\hline Significance & & $* * *$ & & $* * *$ & & $* * *$ & & $* * *$ \\
\hline
\end{tabular}


Table 2. The levels of hygiene indicators on various sites of hides $\left(\log \mathrm{cfu} / \mathrm{cm}^{2}\right)$

\begin{tabular}{|c|c|c|c|c|c|c|c|}
\hline & & $\mathbf{N}$ & $\mathrm{ACC}$ & $\mathbf{N}$ & EC & $\mathbf{N}$ & ECC \\
\hline Category & Hide Site & 10 & Mean \pm SE & 10 & Mean \pm SE & 10 & Mean \pm SE \\
\hline \multirow{5}{*}{$\begin{array}{l}1 \\
\text { Clean and dry }\end{array}$} & Abdominal midline & 10 & $3.01 \pm 0.38$ & 4 & $1.45 \pm 0.14$ & 3 & $1.32 \pm 0.03$ \\
\hline & Brisket & 10 & $3.09 \pm 0.35$ & 4 & $1.52 \pm 0.09$ & 0 & ND \\
\hline & Groin & 7 & $3.29 \pm 0.14$ & 4 & $0.91 \pm 0.14$ & 0 & ND \\
\hline & Rump & 10 & $2.73 \pm 0.09$ & 4 & $1.47 \pm 0.10$ & 0 & ND \\
\hline & Significance & & - & & - & & - \\
\hline \multirow{5}{*}{$\begin{array}{l}2 \\
\text { Slightly dirty }\end{array}$} & Abdominal midline & 10 & $6.22^{\mathrm{a}} \pm 0.34$ & 10 & $1.66^{\mathrm{b}} \pm 0.03$ & 6 & $1.38 \pm 0.08$ \\
\hline & Brisket & 10 & $4.99^{\mathrm{b}} \pm 0.07$ & 10 & $1.88^{\mathrm{ab}} \pm 0.03$ & 0 & ND \\
\hline & Groin & 10 & $5.50^{\mathrm{ab}} \pm 0.06$ & 10 & $1.99^{\mathrm{a}} \pm 0.01$ & 5 & $1.04 \pm 0.04$ \\
\hline & Rump & 10 & $5.21^{\mathrm{ab}} \pm 0.08$ & 10 & $1.74^{\mathrm{ab}} \pm 0.02$ & 5 & $1.10 \pm 0.07$ \\
\hline & Significance & & $*$ & & $*$ & & \\
\hline \multirow{5}{*}{$\begin{array}{l}3 \\
\text { Dirty }\end{array}$} & Abdominal midline & 10 & $6.65 \pm 0.30$ & 10 & $2.87^{\mathrm{a}} \pm 0.03$ & 10 & $2.21^{\mathrm{a}} \pm 0.07$ \\
\hline & Brisket & 10 & $6.45 \pm 0.27$ & 7 & $2.05^{\mathrm{b}} \pm 0.14$ & 6 & $1.43^{\mathrm{b}} \pm 0.11$ \\
\hline & Groin & 10 & $6.60 \pm 0.34$ & 10 & $2.86^{\mathrm{a}} \pm 0.02$ & 4 & $1.84^{\mathrm{ab}} \pm 0.20$ \\
\hline & Rump & 10 & $6.76 \pm 0.24)$ & 10 & $3.09^{\mathrm{a}} \pm 0.06$ & 10 & $1.73^{\mathrm{ab}} \pm 0.12$ \\
\hline & Significance & & - & & $* *$ & & $*$ \\
\hline \multirow{5}{*}{$\begin{array}{l}4 \\
\text { Very dirty }\end{array}$} & Abdominal midline & 10 & $7.94 \pm 0.29$ & 10 & $3.07^{\mathrm{a}} \pm 0.04$ & 10 & $2.40^{\mathrm{a}} \pm 0.04$ \\
\hline & Brisket & 10 & $8.08 \pm 0.34$ & 10 & $1.62^{b} \pm 0.04$ & 3 & $0.78^{\mathrm{b}} \pm 0.43$ \\
\hline & Groin & 10 & $7.45 \pm 0.25$ & 10 & $2.77^{\mathrm{ab}} \pm 0.04$ & 10 & $1.74^{\mathrm{ab}} \pm 0.17$ \\
\hline & Rump & 10 & $7.32 \pm 0.30$ & 10 & $3.42^{\mathrm{a}} \pm 0.03$ & 10 & $2.08^{\mathrm{ab}} \pm 0.15$ \\
\hline & Significance & & - & & $* * *$ & & $*$ \\
\hline \multirow{5}{*}{$\begin{array}{l}5 \\
\text { Filthy and wet }\end{array}$} & Abdominal midline & 10 & $8.38 \pm 0.31$ & 10 & $2.79^{a} \pm 0.03$ & 10 & $1.86^{\mathrm{a}} \pm 0.16$ \\
\hline & Brisket & 10 & $8.64 \pm 0.40$ & 10 & $2.95^{\mathrm{a}} \pm 0.06$ & 9 & $1.29^{\mathrm{b}} \pm 0.17$ \\
\hline & Groin & 10 & $7.62 \pm 0.54$ & 8 & $2.05^{\mathrm{b}} \pm 0.08$ & 6 & $1.31^{\mathrm{b}} \pm 0.12$ \\
\hline & Rump & 10 & $7.69 \pm 0.44$ & 10 & $2.54^{\mathrm{ab}} \pm 0.11$ & 8 & $2.07^{\mathrm{a}} \pm 0.08$ \\
\hline & Significance & & - & & $* *$ & & $*$ \\
\hline
\end{tabular}

\footnotetext{
a,b In a coloumn different superscript letters indicate significant differences *: $\mathrm{P}<0.05$. **: $\mathrm{P}<0.01$. $* * * \mathrm{P}<0.001$
}

$\mathrm{N}$ : The number of samples ND: Not Determined (Detection limit $0.36 \log \mathrm{cfu} / \mathrm{cm}^{2}$ ) 
Table 3. The levels of hygiene indicators on various sites of carcasses $\left(\log \mathrm{cfu} / \mathrm{cm}^{2}\right)$

\begin{tabular}{|c|c|c|c|c|c|c|c|}
\hline Category & Carcass Sites & $\begin{array}{l}N \\
10\end{array}$ & $\begin{array}{c}\text { ACC } \\
\text { Mean } \pm \text { SE }\end{array}$ & $\begin{array}{l}N \\
10\end{array}$ & $\begin{array}{c}\text { EC } \\
\text { Mean } \pm \text { SE }\end{array}$ & $\begin{array}{l}N \\
10\end{array}$ & $\begin{array}{c}\text { ECC } \\
\text { Mean } \pm \text { SE }\end{array}$ \\
\hline \multirow{5}{*}{$\begin{array}{l}1 \\
\text { Clean and dry }\end{array}$} & Flank & 9 & $2.10 \pm 0.11$ & 0 & ND & 0 & ND \\
\hline & Brisket & 8 & $2.07 \pm 0.18$ & 1 & 0.48 & 0 & ND \\
\hline & Groin & 8 & $2.17 \pm 0.07$ & 0 & ND & 0 & ND \\
\hline & Hock & 7 & $2.25 \pm 0.09$ & 0 & ND & 0 & ND \\
\hline & Significance & & - & & & & \\
\hline \multirow{5}{*}{$\begin{array}{l}2 \\
\text { Slightly dirty }\end{array}$} & Flank & 10 & $2.99^{\mathrm{a}} \pm 0.06$ & 0 & ND & 0 & ND \\
\hline & Brisket & 10 & $2.33^{\mathrm{b}} \pm 0.06$ & 0 & ND & 0 & ND \\
\hline & Groin & 8 & $2.51^{b} \pm 0.07$ & 0 & ND & 0 & ND \\
\hline & Hock & 8 & $2.69^{\mathrm{ab}} \pm 0.08$ & 0 & ND & 0 & ND \\
\hline & Significance & & $* * *$ & & & & \\
\hline \multirow{5}{*}{$\begin{array}{l}3 \\
\text { Dirty }\end{array}$} & Flank & 10 & $2.91 \pm 0.14$ & 0 & ND & 0 & ND \\
\hline & Brisket & 10 & $2.46 \pm 0.08$ & 1 & 1.60 & 0 & ND \\
\hline & Groin & 10 & $2.42 \pm 0.09$ & 0 & ND & 0 & ND \\
\hline & Hock & 8 & $2.50 \pm 0.09$ & 0 & ND & 0 & ND \\
\hline & Significance & & - & & & & \\
\hline \multirow{5}{*}{$\begin{array}{l}4 \\
\text { Very dirty }\end{array}$} & Flank & 10 & $2.06^{\mathrm{b}} \pm 0.09$ & 0 & ND & 0 & ND \\
\hline & Brisket & 10 & $2.18^{\mathrm{ab}} \pm 0.15$ & 0 & ND & 0 & ND \\
\hline & Groin & 10 & $2.43^{\mathrm{ab}} \pm 0.10$ & 0 & ND & 0 & ND \\
\hline & Hock & 8 & $2.60^{\mathrm{a}} \pm 0.14$ & 0 & ND & 0 & ND \\
\hline & Significance & & $*$ & & & & \\
\hline \multirow{5}{*}{$\begin{array}{l}5 \\
\text { Filthy and wet }\end{array}$} & Flank & 10 & $2.20 \pm 0.08$ & 0 & ND & 0 & ND \\
\hline & Brisket & 9 & $2.38 \pm 0.09$ & 1 & 2.03 & 0 & ND \\
\hline & Groin & 9 & $2.26 \pm 0.06$ & 0 & ND & 0 & ND \\
\hline & Hock & 10 & $2.35 \pm 0.10$ & 0 & ND & 0 & ND \\
\hline & Significance & & - & & & & \\
\hline
\end{tabular}

${ }^{\mathrm{a}, \mathrm{b}}$ In a coloumn different superscript letters indicate significant differences *: $\mathrm{P}<0.05$. ${ }^{* * *} \mathrm{P}<0.001$.

$\mathrm{N}$ : The number of samples ND: Not Determined (Detection limit $0.36 \log \mathrm{cfu} / \mathrm{cm}^{2}$ )

were also inconsistent with the cleanliness scores (Table 1). Data of EC and ECC could not be analyzed due to the detection limit of the microbiological examinations which was $0.36 \log \mathrm{cfu} / \mathrm{cm}^{2}$.

The results of the samples taken from various parts of hides did not show any significant differences for ACC except in Category 2 (Table 2). In this group, there was a significant difference between abdominal midline and brisket $(\mathrm{P}<0.05)$. No differences were found between other groups $(\mathrm{P}>0.05)$. Despite the significant differences between sampling sites for $\mathrm{EC}(\mathrm{P}<0.05, * *: \mathrm{P}<0.01$, $* * *: \mathrm{P}<0.001)$, the increase in the microbial counts for sampling sites obtained from different categories was not consistent. The level of ECC from different parts of hides increased with increasing category level, but the significant differences $(\mathrm{P}<0.05)$ between parts related to categories were inconsistent. The increase in the ECC was not relevant to the categories either.

The ACC levels on different parts of the examination sites varied. Only in 2 categories (Category 2 and Category 4), there were significant differences between the examined parts. In Category 2 the highest value was on the flank area $\left(2.99 \log \mathrm{cfu} / \mathrm{cm}^{2}\right)$ whereas the lowest was on 
the brisket area with a level of $2.33 \log \mathrm{cfu} / \mathrm{cm}^{2}$ $(\mathrm{P}<0.001)$. For Category 4, the lowest ACC was observed on the flank $\left(2.06 \log \mathrm{cfu} / \mathrm{cm}^{2}\right)$ and the highest value was found on the hock site $\left(2.60 \log \mathrm{cfu} / \mathrm{cm}^{2}\right)$. For EC levels, plates from only 3 samples in different categories showed bacterial growth and yielded positive microbiological findings (Table 3). For ECC no bacterial growth was determined on the plates inoculated from the neat dilution of the samples due to the detection limit of the microbiological examinations. Therefore, data of EC and ECC could not be statistically analyzed.

\section{DISCUSSION}

Animals may carry a large number of different microbiota in their gastrointestinal tract and on their hide when they reach the slaughterhouse. Hair and feet are contaminated with fecal material, especially when they are raised in intensive breeding systems. The main source of carcass contamination within the slaughter line is the feces which is in contact with the hides of the slaughtered animals scored with low cleanliness (7). Therefore, the assessment of E. coli and Enterobacteriaceae's presence on the carcass, which are considered as the most reliable indicators for contamination, can be used to evaluate the hygienic status during the slaughtering process (22). ACC evaluation provides information concerning the shelf life (23). However, the carcass indicators ACC and EC reflect the hygienic level, but they cannot estimate the possibility for occurrence of hazards, per se (24).

The current study showed that a higher cleanliness level (from 1 to 5) in cattle was associated with higher ACC on hides (Table 1). This was in agreement with several other studies showing a consistent and significant increasing trend in the ACC obtained from the hides categorized according to the cleanliness scores $(6,25)$. The observed increasing trend of EC and ECC levels on the hides along with the higher cleanliness categories was almost insignificant and inconsistent. Johanson et al. (26) and Serranio et al. (6) stated that hide portions in direct contact with soil/bedding (brisket, abdominal midline) were the most contaminated sites in all cleanliness categories. The results presented in this study were not concurring with other reports which noted differences between the parts in the same categories, which in most cases were insignificant, inconsistent, or nonexistent. Only for EC in Category 5 (filthy and wet animals), brisket and abdominal midline were heavily contaminated compared to other parts on hides.

Cattle hides generally have high bacterial loads, thus were indicated as the major source for carcass contamination $(27,28)$. It was stated by several researchers that contamination mainly occurs during the de-hiding process and bacterial counts obtained from carcasses after de-hiding are correlated with those on hides $(9,29)$. But, others $(8,30,31)$ reported a limited effect of hide dirtiness on carcass contamination. Reneau et al. (32) and Ruud et al. (33) stated that the presentation of clean cattle for slaughter and good slaughter hygiene were fundamental prerequisites for reducing carcass contamination. Buncic et al. (10) observed that results from studies on hide cleanliness, the microbiological status of hides and carcasses were inconsistent, and further studies were necessary. Hauge et al. (25) stated that the dirtiest animals were not associated with significantly higher carcass contamination than the cleanest carcasses, either at the start or the end of the slaughter line. A study conducted by Jericho et al. (30) showed that there was only a weak correlation between the mean numbers of aerobes recovered from corresponding sites on groups of carcasses and the total score for visible contamination at each group of corresponding sites. Although the level of bacterial contamination increases with the consecutively higher cleanliness categories on the hide of the animals, the reflection of this increasing trend on carcasses and different parts of the carcasses are not consistent, which is in agreement with other reports $(8,25,30)$.

The contamination rate and level of indicators on the carcasses might be affected by the hygiene status of the slaughterhouse and slaughtering procedures. Ridell and Korkeala (34) reported that contamination of carcasses from the dirty sites of the hides was highly correlated with the skills of the operator and the employed manual skinning methods. The operators' hands might also be the source of contamination from hide/ fleece to carcasses. Nastasijevic et al. (24) reported that cross-contamination at the de-hiding and evisceration stages can be achieved by efficient trimming and washing procedures, routine sanitization of knives, equipment, and food contact surfaces, maintaining control of process hygiene, and effective monitorization of CCPs. Employment of Good Manufacturing Practices (GMPs) and Standard Sanitation Operating Procedures (SSOPs) (compliance with GHP procedures) in hygienic carcass hide removal, would additionally aid in minimizing cross-contamination (35). The 
slaughterhouse which was used for sample collection for the current study had an effective HACCP procedure, GMP ongoing applications, and strict monitoring procedures. It was observed that the hygienic procedures applied in the slaughterhouse had very efficient and strict control of the workers and great attention was paid to avoid unnecessary contact between carcasses and dirty hands, knives, aprons, equipment. The premise utilized a twoknife system with a momentary dipping of the knife in hot water $\left(82-85^{\circ} \mathrm{C}\right)$ circulating on knife-holding rocks on the slaughtering line with fixed worker positions. Therefore, each knife was sanitized after its use on a single carcass and/or whenever it was necessary. The operators were working on either slaughtering, dressing, or eviscerating positions without rotations which might also have had some contributions to reducing the contamination rate. The automated conveyor line was working automatically ensuring minimum contact with operators during processing. These factors might have contributed to the high ACC level observed on the hide, very low level of ACC on the carcasses, and the EC level ended up with no positive carcass sample. It is generally accepted that contamination of carcasses with feces in slaughterhouses working under strict hygienic principles is very rare. It was also suggested that slaughterhouse employees especially butchers working at the de-hiding point of the slaughter line should be informed and well trained on the hygienic procedures (9).

\section{CONCLUSION}

In conclusion, it was stated that although the cleanliness of the animal possesses great importance for the microbiological quality of carcasses, the hygiene provided in the slaughterhouse and processing line is one of the most important factors to reduce cross-contamination occurring during processing and to have low microbiological contamination on the carcasses.

\section{CONFLICT OF INTEREST}

The authors declare that they have no known competing financial interests or personal relationships that could have appeared to influence the work reported in this paper.

\section{ACKNOWLEDGEMENTS}

This study was supported by Aydin Adnan Menderes University Scientific Research Project Coordination (Project Number: VTF-14041).

\section{AUTHORS' CONTRIBUTION}

EOG was included in the methodology planning, conceptualization, supervision, and writing of this manuscript. BK was included in conceptualization, analysis, resources, investigation, validation, analysis, and writing-editing of the manuscript. PK and CS performed the validation, analysis, data curation, and project administration.

\section{REFERENCES}

1. Antic, D., Blagojevic, B., Ducic, M., Mitrovic, R., Nastasijevic, I., Buncic, S. (2010). Treatment of cattle hides with Shellac-in-ethanol solution to reduce bacterial transferability - A preliminary study. Meat Sci. 85(1): 77-81.

https://doi.org/10.1016/j.meatsci.2009.12.007

PMid:20374868

2. Obaidat, M.M. (2020). Prevalence and antimicrobial resistance of Listeria monocytogenes, Salmonella enterica and Escherichia coli O157:H7 in imported beef cattle in Jordan. Comp Immunol Microb Infect Dis. 70, 101447.

https://doi.org/10.1016/j.cimid.2020.101447

PMid:32105836

3. Gill, C.O. (1998). Microbiological contamination of meat during slaughter and butchering of cattle, sheep and pigs. Microbiol Meat Poult. 118-157.

4. Zweifel, C., Capek, M., Stephan, R. (2014). Microbiological contamination of cattle carcasses at different stages of slaughter in two abattoirs. Meat Sci. 98(2): 198-202.

https://doi.org/10.1016/j.meatsci.2014.05.029

PMid:24967539

5. Cartier, P. (1994). Use of the ownership status of large cattle as an indicator of the microbial load of their leather. Meat and Meat Products 15(4): 119-122. [in French]

6. Serraino, A., Bardasi, L., Riu, R., Pizzamiglio, V., Liuzzo, G., Galletti, G., Giacometti, F., Merialdi, G. (2012). Visual evaluation of cattle cleanliness and correlation to carcass microbial contamination during slaughtering. Meat Sci. 90(2): 502-506. https://doi.org/10.1016/j.meatsci.2011.08.001 PMid:21906889 
7. Blagojevic, B., Antic, D., Ducic, M., Buncic, S. (2012). Visual cleanliness scores of cattle at slaughter and microbial loads on the hides and the carcases. Vet Rec. 170(22): 563.

https://doi.org/10.1136/vr.100477

PMid:22505244

8. Van Donkersgoed, J., Jericho, K.W.F., Grogan, H., Thorlakson, B. (1997). Preslaughter hide status of cattle and the microbiology of carcasses. J Food Prot. 60(12): 1502-1508.

https://doi.org/10.4315/0362-028X-60.12.1502

PMid:31207746

9. Antic, D., Blagojevic, B., Ducic, M., Nastasijevic, I., Mitrovic, R., Buncic, S. (2010). Distribution of microflora on cattle hides and its transmission to meat via direct contact. Food Control 21(7): 1025-1029. https://doi.org/10.1016/j.foodcont.2009.12.022

10. Buncic, S., Nychas, G.J., Lee, M.R.F., Koutsoumanis, K., Hébraud, M., Desvaux, M., Chorianopoulos, N., et al. (2014). Microbial pathogen control in the beef chain: Recent research advances. Meat Sci. 97(3): 288-297. https://doi.org/10.1016/j.meatsci.2013.04.040 PMid:23688797

11. Food Standards Agency [Internet]. Red meat safety \& clean livestock. Published by the Food Standards Agency June 2002 [Reprinted March 2004].

https://www.foodstandards.gov.scot/downloads/ Red_meat_safety_and_clean_livestock.pdf

12. European Commission (2004) [Internet]. Regulation (EC) $\mathrm{N}^{\circ} 852 / 2004$ of the European Parliament and of the Council of 29 April 2004 on the hygiene of foodstuffs. Official Journal of the European Union, L 139(1), 54.

https:/eur-lex.europa.eu/eli/reg/2004/852/oj

13. European Commission (2004) [Internet]. Regulation (EC) $N^{\circ} 853 / 2004$ of the European Parliament and of the Council of 29 April 2004 laying down specific hygiene rules for on the hygiene of foodstuffs. Official Journal of the European Union, L 139(853), 55. https://eur-lex.europa.eu/legal-content/en/ ALL/?uri=CELEX\%3A32004R0853

14. Food Standards Agency [Internet]. Clean beef cattle for slaughter. A guide for producers. Published by the Food Standard Agency October 2007.

https://www.foodstandards.gov.scot/downloads/ cleanbeefsaf1007.pdf

15. AFSCA (2006) [Internet]. Scientific committee of the federal agency for the safety of the food chain. 2006. D/2006/10413/2 - Good condition of the fleece for sour meat. Bruxelles: Gil Houins, 2006b. [in French] https://www.favv-afsca.be/publicationsthematiques/_ documents/Folder_VC_FR_26-01-2018_web.pdf
16. Bastien, D., Lucbert, J., Cartier, P. (2006). Cattle cleanliness at slaughter: observations report, factors involved and a method to grade. Renc Rech Ruminants. 13, 317-320. [in French]

17. Regulation of special hygiene rules for animal food. Law of authorization: 5996. Official gazette of publication: 27.12.2011. Nr. 28155 .

18. Cenci-Goga, B.T., Miraglia, D., Ranucci, D., Branciari, R., Budelli, L., McCrindle, C.M., Cioffi, A., Mammoli, R. (2007). An in vitro system for the comparison of excision and wet-dry swabbing for microbiological sampling of beef carcasses. J Food Prot. 70(4): 930-936.

https://doi.org/10.4315/0362-028X-70.4.930 PMid:17477263

19. ISO-ISO 4833-2:2013 [Internet]. Microbiology of the food chain - Horizontal method for the enumeration of microorganisms - Part 2: Colony count at 30 degrees $\mathrm{C}$ by the surface plating tech-nique. International Standard 2013, Geneva, Switzerland. [Retrieved February 19, 2021]. https://www.iso.org/standard/29824.html

20. ISO - ISO 21528-2:2004 [Internet]. Microbiology of food and animal feeding stuffs -Horizontal methods for the detection and enumeration of Enterobacteriaceae - Part 2: Colony-count method. [Retrieved February 19, 2021]. https://www.iso.org/standard/34566.html

21. ISO - ISO 16649-2:2001 [Internet]. Microbiology of food and animal feeding stuffs -horizontal method for the enumeration of beta-glucuronidase-positive Escherichia coli - Part 2: Colony-count technique at 44 degrees $\mathrm{C}$ using 5-bromo-4-chloro-3-indolyl beta-D-glucuronide. [Retrieved February 19, 2021]. https://www.iso.org/standard/29824.html

22. Barco, L., Belluco, S., Roccato, A., Ricci, A. (2015). A systematic review of studies on Escherichia coli and Enterobacteriaceae on beef carcasses at the slaughterhouse. Int J Food Microbiol. 207, 30-39. https://doi.org/10.1016/j.ijfoodmicro.2015.04.027 PMid:25978803

23. ICMSF (International Commission on Microbiological Specifications for Foods) (2000). Microorganisms in foods 6: Microbial ecology of food commodities. Maryland: Aspen Publishers Inc.

24. Nastasijevic, I., Tomasevic, I., Smigic, N., Milicevic, D., Petrovic, Z., Djekic, I. (2016). Hygiene assessment of Serbian meat establishments using different scoring systems. Food Control 62, 193-200. https://doi.org/10.1016/j.foodcont.2015.10.034

25. Hauge, S., Nafstad, O., Røtterud, O.J., Nesbakken, T. (2012). The hygienic impact of categorisation of cattle by hide cleanliness in the abattoir. Food Control 27(1): 100-107. https://doi.org/10.1016/j.foodcont.2012.03.004 
26. Johanson,L.,Underdal,B., Grøsland, K., Whelehan, O.P., Roberts, T.A. (1983). A survey of the hygienic quality of beef and pork carcasses in Norway. Acta Vet Scand. 24(1): 1-13.

https://doi.org/10.1186/BF03546753

PMid:6869140 PMCid:PMC8291255

27. Arthur, T.M., Bosilevac, J.M., Nou, X., Shackelford, S.D., Wheeler, T.L., Kent, M.P., Jaroni, D., et al. (2004). Escherichia coli $\mathrm{O} 157$ prevalence and enumeration of aerobic bacteria, Enterobacteriaceae, and Escherichia coli $\mathrm{O} 157$ at various steps in commercial beef processing plants. J Food Prot. 67(4): 658-665. https://doi.org/10.4315/0362-028X-67.4.658 PMid:15083715

28. Reid, C.A., Small, A., Avery, S.M., Buncic, S. (2002). Presence of food-borne pathogens on cattle hides. Food Control 13(6-7): 411-415. https://doi.org/10.1016/S0956-7135(01)00050-0

29. Garcia, A.B., Steele, W.B., Reid, S.W.J., Taylor, D.J. (2010). Risk of carcass contamination with Campylobacter in sheep sent for slaughter into an abattoir in Scotland. Prev Vet Med. 95(1-2): 99-107. https://doi.org/10.1016/j.prevetmed.2010.03.008 PMid:20381181

30. Jericho, K.W.F., Bradley, J.A., Gannon, V.P.J., Kozub, G.C. (1993). Visual demerit and microbiological evaluation of beef carcasses: Methodology. J Food Prot. 56(2): 114-119.

https://doi.org/10.4315/0362-028X-56.2.114

PMid:31084117
31. Mackey, B.M., Roberts, T.A. (1993). Improving slaughter hygiene using HACCP and monitoring. Fleischwirtschaft Int. 2, 40-45.

32. Reneau, J.K., Seykora, A.J., Heins, B.J. (2003). Relationship of cow hygiene scores and SCC. Proc Natl Mast Coun. Madison, WI. 362-363.

33. Ruud, L.E., Bøe, K.E., Østerås, O. (2010). Risk factors for dirty dairy cows in Norwegian freestall systems. J Dairy Sci. 93(11): 5216-5224. https://doi.org/10.3168/jds.2010-3321 PMid:20965336

34. Ridell, J., Korkeala, H. (1993). Special treatment during slaughtering in Finland of cattle carrying an excessive load of dung; Meat hygienic aspects. Meat Sci. 35(2): 223-228. https://doi.org/10.1016/0309-1740(93)90052-J

35. Alvseike, O., Røssvoll, E., Røtterud, O.J., Nesbakken, T., Skjerve, E., Prieto, M., Sandberg, M., et al. (2019). Slaughter hygiene in European cattle and sheep abattoirs assessed by microbiological testing and hygiene performance rating. Food Control 101, 233-240. https://doi.org/10.1016/j.foodcont.2019.01.033 